\title{
Prevalence of intestinal helminths and associated factors among school children of Medebay Zana wereda; North Western Tigray, Ethiopia 2017
}

\author{
Tsega Teshale ${ }^{1^{*}}\left(\mathbb{D}\right.$, Shewaye Belay ${ }^{3}$, Desalegn Tadesse ${ }^{3}$, Abraham Awala $^{3}$ and Girmay Teklay ${ }^{2}$
}

\begin{abstract}
Objective: To assess the prevalence of intestinal helminth infections and associated factors among primary school children of Medebay Zana wereda, a northwestern zone of Tigray, northern Ethiopia from March to April 2017.

Result: The prevalence of intestinal helminths was $12.7 \%$. The highest prevalence of intestinal helminth infections was observed in the age group of 11-14 years old and the most prevalent helminths species were Schistosoma mansoni. Mothers' level of education [AOR $=0.27$ [0.13-0.58]], place of defecation [AOR $=2.63,95 \% \mathrm{Cl} 1.14-6.02]$ ], hand wash before meals $[\mathrm{AOR}=9.0,95 \% \mathrm{Cl} 3.72-21.74]]$, hand wash after defecation [AOR $=5.77$ [1.78-18.63]] and eating unwashed vegetables $[A O R=5.67$ [2.19-14.73]] were associated with higher risk of having intestinal helminths detected in stool. In the study area the risk of detecting intestinal helminths in their stool were more associated the improper personal hygiene of the children.
\end{abstract}

Keywords: Helminths, STH, Schistosoma, Schistosomiasis, Mother's education, Open defecation

\section{Introduction}

About 610 million school age children of the world are at risk of infection with a common intestinal helminths [1] like hookworm, A. lumbricoides, T. trichiura, Strongyloides stercoralis, Hymenolepis nana and Schistosoma mansoni $[2,3]$. Those infections are resulted from socioeconomic factors, cultural practices and poor sanitation which are transmitted by ingestion of soil contaminated egg, poor hand hygiene, eating unwashed fruit, under cooked infected meat and poorly washed vegetable [4]. Skin penetration while walking bare foot on larvae infected soil and skin penetration by swimming in cercariae bearing water are anther transmission mechanism of helminths [5, 6].

Infestation by intestinal helminths is the major public health problem which causes chronic inflammatory

\footnotetext{
*Correspondence: tsegateshale4@gmail.com

1 Department of Laboratory, Aksum University, Po Box: 298, Aksum, Tigray, Ethiopia

Full list of author information is available at the end of the article
}

disorder such as chronic anemia, growth stunting, protein-calorie malnutrition, fatigue, poor cognitive performance, reduce long term survival, diminished physical fitness and school attendance in school-age children [7, 8]. Intestinal helminths infections like acute and chronic complications of $S$. mansoni also cause very severe consequences like abdominal pain, diarrhea, hepatosplenomegaly, portal hypertension, and upper gastrointestinal bleeding [9].

Worldwide, about 100 million of intestinal worm harboring school-children experience stunting or wasting $[10,11]$. Severity in intestinal helminths resulted from fluctuation in metabolic rate, anorexia, chronic anemia, obstructing intestinal lumen of children associated with heavy worm-load [12].

In Ethiopia, intestinal helminths are resulted from poor environmental sanitation, unsafe human waste disposal systems, lack of safe water supply and low socio-economic status of the country [13-18]. The main reason for their persistent presence everywhere is due to frequently

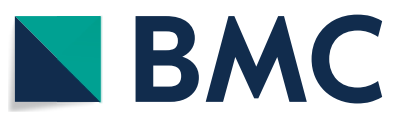

C The Author(s) 2018. This article is distributed under the terms of the Creative Commons Attribution 4.0 International License (http://creativecommons.org/licenses/by/4.0/), which permits unrestricted use, distribution, and reproduction in any medium, provided you give appropriate credit to the original author(s) and the source, provide a link to the Creative Commons license, and indicate if changes were made. The Creative Commons Public Domain Dedication waiver (http://creativecommons.org/ publicdomain/zero/1.0/) applies to the data made available in this article, unless otherwise stated. 
low rank in the list of priorities in public health programs because the effect of helminthic infections are not directly measured explicitly in terms of mortality figures [19].

Though studies on intestinal helminths and associated factors have been conducted in different parts of Ethiopia [10, 20-24], the prevalence of intestinal infection in the local area has not yet properly documented. This study will help for school community to improve their environmental sanitation and to health office of Medebay Zana wereda to design periodic mass-deworming program. Therefore, the aim of this study was to assess the prevalence of intestinal helminths and associated factors among School Children of Medebay Zana wereda; Tigray, Ethiopia.

\section{Main text}

\section{Study design and setting}

A school based cross-sectional study design was used to collect data in eight primary schools of Medebay Zana wereda from March to April 2017, located at $282 \mathrm{~km}$ from Mekelle and about $1060 \mathrm{~km}$ far from Addis Ababa. Its geographical location is between $38^{\circ} 20^{\prime} \mathrm{E}$ longitude and $14^{\circ} 06^{\prime} \mathrm{N}$ latitudes [25]. About $9 \%$ of all houses in urban had access to safe drinking water and $4 \%$ of rural houses had toilet facilities [26].

\section{Sample size calculation}

The sample size was calculated using single population proportion formula by taking the highest sample giving from both prevalence and associated factors. We using the previous prevalence from a study done in Enderta [10] i.e. $41.46 \%$ with $5 \%$ margin of error and $95 \%$ confidence interval. The final sample size with $10 \%$ contingency was 410.

\section{Sampling technique}

From the total primary schools in the wereda, eight schools were selected randomly four from rural and four from urban areas. From the eight selected schools with 1-8 grades, 410 children were taken by using simple random sampling technique. Kato-katz technique were also use for the laboratory investigation.

\section{Source and study population}

All students in elementary schools of Medebay Zana wereda were considered as source population and all randomly selected students grade 1-8 in eight selected elementary schools were considered as our study subjects.

\section{Data collection procedure and instruments}

The data was collected using interviewer administered structured questionnaire adapted from study done in
Lumam town, north west Ethiopia [27] and stool sample. The adapted questionnaire was modified and contextualized to fit the local situation and research objective. After obtaining oral consent from teachers and parents and assent from the students, each student was given a coded stool collection container (clean plastic cup) and applicator sticks and instructed to bring $6 \mathrm{~g}$ of his/her own fresh stool. Two BSc in graduates' in laboratory technology were recruited as data collectors and one senior professional nurse for screening of complications. Stool collection was supervised throughout the time. On delivery of the stool specimen the code of parasitological investigation was filled properly on the prepared parasitological format that was attached with questionnaire.

Following stool examination using Kato-Katz technique, children who become positive for $S$. mansoni infection were checked for palpable splenomegaly and hepatomegaly. Those found with splenomegaly and hepatomegaly were informed to their parents to take them to hospital for further checkup and for free care of their complications.

\section{Study variables}

The dependent variable was detection of helminths in stool samples and the independent variables were sociodemographic factors like: age, sex, fathers and mothers level of education, residence and other associated factors like:- shoes wearing habit, place of defecation, water source, hand washing habit before meal, hand washing habit after defecation and habit of eating improperly washed raw vegetables. Those variables was asked to the caretaker of the children.

\section{Data quality assurance}

Training was given for data collectors. The questionnaire was prepared originally in English and then translated into the local language of study area (Tigrigna). Questionnaires were pretested on 5\% of the sample size at Mekane-Eyesus primary school. All reagents were checked for expired date. Close supervision was done by the principal investigator.

\section{Data processing and analysis}

The Data was coded, entered, cleaned, edited and analyzed using SPSS ver.22. The prevalence of intestinal helminths was reported in percentages of detected helminths in stool of the children. Binary logistic regression was used to examine the association between the dependent variable and each independent variable. Variables which showed statistical significance during bivariate analysis at $\mathrm{p}$ value $\leq 0.20$ were entered to multivariate logistic regression to isolate an independent effect of the predictors. Adjusted odds ratios (AOR) with 95\% CI, 
were estimated to assess the strength of associations and statistical significance was declared at a p-value $<0.05$.

\section{Results}

Socio-demographic characteristics of the study subjects

A total of 410 school age children were examined for intestinal helminths with stool sampling success rate of $100 \%$. Out of these respondents $58.5 \%$ were males and 238 (58\%) were live in the rural area. About 238 (48.8\%) of the participants were belonged to households with a family size range from 4 to 6 . The mean age of study participants was $11.41 \pm 2.202$ ranging 9-19 years old (Table 1).

\section{Prevalence of intestinal helminths}

In this study $12.7 \%$ (CI 9.60-16.30) of the participants have at least one intestinal helminths detected in their stool. The detected helminths in stool was high in the age range of 11-14 years old with prevalence of 36 (13.5\%). In the study $405(98.8 \%)$ of the children uses river water. Among them 39 (9.6\%) were had intestinal helminths and $4(9.8 \%)$ of them uses the river water for drinking, washing and swimming. About 15 (18\%) of the children did not wear shoes and 32 (12.5\%) were cross the flowing river and irrigational area in their daily activity (Table 1 ).

\section{Distribution of single and double infection}

Five different helminthic species were recorded (A. lumbricoides, Hookworm, S. mansoni, H. nana and T. trichiura). Out of the detected helminths infection 33 (63.5\%) were occur in the age range of 11-14 years. From the total intestinal helminths detected, 49 (94.2\%) of the children were having single infection of the helminths and 3 (5.8\%) were co-infected with two different helminths $A$. lumbricoides and T. trichiura (Table 2).

\section{Splenomegaly and hepatomegaly with S. mansoni}

In this study, the most predominant helminthic infection was S. mansoni 20 (38.5\%). From all children infected with S. mansoni, $5 \%$ were with splenomegaly and $25 \%$ had hepatomegaly and were linked to hospital for free care.

\section{Risk factors for intestinal helminths infections}

In the bivariate logistic regression at $\mathrm{p}$-value of $\leq 0.2$, residence, mother's educational status, place of defecation, hand washing before meal, hands washing after defecation, shoes wearing habit and eating unwashed vegetable were statistically significant with having intestinal helminths infections in the stool sample.

After entering these variables to multivariate analysis by using backward elimination method, Mother's educational status, place of defecation, hand washing
Table 1 Socio-demographic characteristics with respect to their prevalence of intestinal helminths of wereda Medebay Zana, Tigray, Ethiopia, 2017

\begin{tabular}{|c|c|c|c|}
\hline \multirow{2}{*}{$\begin{array}{l}\text { Socio-demographic } \\
\text { characteristics }\end{array}$} & \multicolumn{2}{|c|}{ Intestinal helminths } & \multirow[t]{2}{*}{ Total } \\
\hline & Positive (\%) & Negative (\%) & \\
\hline \multicolumn{4}{|l|}{ Age } \\
\hline $6-10$ & $11(12.5)$ & $77(87.5)$ & 88 \\
\hline $11-14$ & $36(13.5)$ & $230(86.5)$ & 266 \\
\hline $15-19$ & $5(8.9)$ & $51(91.1)$ & 56 \\
\hline \multicolumn{4}{|l|}{ Gender } \\
\hline Male & $27(11.2)$ & $213(88.8)$ & 240 \\
\hline Female & $25(14.5)$ & $145(85.3)$ & 170 \\
\hline \multicolumn{4}{|l|}{ Religion } \\
\hline Orthodox & $49(13)$ & $340(87)$ & 389 \\
\hline Muslim & $3(14.3)$ & $18(85.7)$ & 21 \\
\hline \multicolumn{4}{|l|}{ Residence } \\
\hline Urban & $30(17.4)$ & $142(82.6)$ & 172 \\
\hline Rural & $22(22)$ & $216(90.8)$ & 238 \\
\hline \multicolumn{4}{|l|}{ Family size } \\
\hline $1-3$ & $3(11.1)$ & $24(88.9)$ & 27 \\
\hline $4-6$ & $31(15.5)$ & $169(84.5)$ & 200 \\
\hline$>6$ & $18(9.8)$ & $165(90.2)$ & 183 \\
\hline \multicolumn{4}{|l|}{ Mother education } \\
\hline Illiterate & $21(9.2)$ & $208(90.8)$ & 229 \\
\hline Literate & $31(17.1)$ & $150(41.9)$ & 181 \\
\hline \multicolumn{4}{|l|}{ Father's education } \\
\hline Illiterate & $31(14.7)$ & $108(85.3)$ & 211 \\
\hline Literate & $21(10.6)$ & $179(89.4)$ & 199 \\
\hline \multicolumn{4}{|l|}{ Use river water } \\
\hline Yes & $39(9.6 \%)$ & $366(90.4 \%)$ & 405 \\
\hline No & $2(40 \%)$ & $3(60 \%)$ & 5 \\
\hline \multicolumn{4}{|l|}{ Purpose to use river water } \\
\hline To drink wash and swim & $4(9.8 \%)$ & $37(90.2 \%)$ & 41 \\
\hline Only to wash and swim & $37(10 \%)$ & $332(90 \%)$ & 369 \\
\hline \multicolumn{4}{|l|}{ Shoes wearing } \\
\hline Yes & $26(8 \%)$ & $301(92 \%)$ & 327 \\
\hline No & $15(18 \%)$ & $68(82 \%)$ & 83 \\
\hline \multicolumn{4}{|c|}{ Cross flowing river and irrigational area } \\
\hline Yes & $32(12.5 \%)$ & $225(87.5 \%)$ & 257 \\
\hline No & $9(5.9 \%)$ & $144(94.1 \%)$ & 153 \\
\hline
\end{tabular}

before meal, hands washing after deification and eating unwashed vegetable were statistically significant with the detected intestinal helminthic infections in the stool at p-value $<0.05$ (Table 3).

\section{Discussion}

The overall prevalence of intestinal helminths recorded in this study was $12.7 \%$. This was almost comparable with the study done in Were-abay $12.22 \%$ [16] and Babile 
Table 2 Distribution of single and double infection of wereda Medebay Zana, Tigray, Ethiopia, 2017

\begin{tabular}{|c|c|c|c|c|c|c|c|}
\hline \multirow{2}{*}{$\begin{array}{l}\text { Variables } \\
\mathrm{N}=52\end{array}$} & \multicolumn{5}{|c|}{ Single infection } & \multirow{2}{*}{$\begin{array}{l}\text { Double infection } \\
\text { A. lumbricoides and T. } \\
\text { trichiura }\end{array}$} & \multirow[t]{2}{*}{ Total (\%) } \\
\hline & S.mansoni & A. lumbricoides & Hookworm & H. nana & $\begin{array}{l}\text { Total } \\
\text { n (\%) }\end{array}$ & & \\
\hline \multicolumn{8}{|l|}{ Sex } \\
\hline Male & $12(23 \%)$ & $4(7.7 \%)$ & $6(11.5 \%)$ & $3(5.8 \%)$ & 25 (48\%) & $2(3.8 \%)$ & $2(3.8 \%)$ \\
\hline Female & $8(15.4 \%)$ & $2(3.8 \%)$ & $11(21.2 \%)$ & $3(5.8 \%)$ & $24(46 \%)$ & $1(1.9 \%)$ & $1(1.9)$ \\
\hline Total & 20 (38.5\%) & $6(11.5 \%)$ & 17 (32.7\%) & $6(11.5 \%)$ & 49 (94\%) & $3(5.8 \%)$ & $3(5.8)$ \\
\hline \multicolumn{8}{|l|}{ Age } \\
\hline $6-10$ & $4(7.7 \%)$ & $2(3.8 \%)$ & $4(7.7 \%)$ & $1(1.9 \%)$ & $11(21.2 \%)$ & 0 & 0 \\
\hline $11-14$ & 14 (27\%) & $4(7.7 \%)$ & $11(21.2 \%)$ & $4(7.7 \%)$ & $33(63.5 \%)$ & $3(5.8 \%)$ & $3(5.8 \%)$ \\
\hline $15-19$ & $2(3.8 \%)$ & 0 & $2(3.8 \%)$ & $1(1.9 \%)$ & $5(9.6 \%)$ & 0 & 0 \\
\hline Total & 20 (38.5\%) & $6(11.5 \%)$ & 17 (32.7\%) & $6(11.5 \%)$ & 49 (94\%) & $3(5.8 \%)$ & $3(5.8 \%)$ \\
\hline \multicolumn{8}{|l|}{ Residence } \\
\hline Urban & 13 (25\%) & $4(7.7 \%)$ & $9(17.3 \%)$ & $1(1.9 \%)$ & 27 (51.9\%) & 0 & 0 \\
\hline Rural & $7(13.5 \%)$ & $2(3.8 \%)$ & $8(15.4 \%)$ & 5 (9.6\%) & $22(42.3 \%)$ & $3(5.8 \%)$ & $3(5.8 \%)$ \\
\hline Total & 20 (38.5\%) & $6(11.5 \%)$ & $17(32.7 \%)$ & $6(11.5 \%)$ & 49 (94.2\%) & $3(5.8 \%)$ & \\
\hline
\end{tabular}

Table 3 Risk factors of intestinal helminth infections of wereda Medebay Zana north western Tigray, Ethiopia, 2017

\begin{tabular}{|c|c|c|c|c|c|}
\hline \multirow[t]{2}{*}{ Variables } & \multicolumn{2}{|c|}{ Laboratory result } & \multirow[t]{2}{*}{$\mathrm{CO}(\mathrm{Cl} 95 \%)$} & \multirow[t]{2}{*}{ AOR (Cl 95\%) } & \multirow[t]{2}{*}{$\mathrm{p}$-value } \\
\hline & $\begin{array}{l}\text { Positive } \\
\text { n (\%) }\end{array}$ & $\begin{array}{l}\text { Negative } \\
\mathrm{n}(\%)\end{array}$ & & & \\
\hline \multicolumn{6}{|c|}{ Level of education of mother } \\
\hline Illiterate & $21(9.2)$ & $208(90.8)$ & $0.489[0.270-0.883]$ & $0.272[0.127,0.580]$ & $0.001^{*}$ \\
\hline Literate & $31(17.1)$ & $150(82.9)$ & 1 & 1 & \\
\hline \multicolumn{6}{|c|}{ Place of defecation } \\
\hline Latrine & $9(6)$ & $142(94)$ & 1 & 1 & $0.023^{*}$ \\
\hline Open field & $43(16.6)$ & $216(83.3)$ & $3.329[1.574-7.037]$ & $2.626[1.145,6.020]$ & \\
\hline \multicolumn{6}{|c|}{ Hand washing before meal } \\
\hline Yes & $10(5)$ & $209(95)$ & 1 & 1 & $0.000^{*}$ \\
\hline No & $42(22)$ & $149(78)$ & $5.959[2.898,12.25]$ & $8.999[3.725,21.74]$ & \\
\hline \multicolumn{6}{|c|}{ Hand washing after defecation } \\
\hline Always & $5(9)$ & $80(94.1)$ & 1 & 1 & $0.003^{*}$ \\
\hline Sometimes & $19(9)$ & $192(91)$ & $1.583[0.571-4.387]$ & $1.536[0.463,5.094]$ & \\
\hline Not at all & $28(24.6)$ & $86(75.4)$ & $5.209[1.918,14.14]$ & $5.766[1.784,18.63]$ & \\
\hline \multicolumn{6}{|c|}{ Eating unwashed vegetable } \\
\hline Always & $24(28)$ & $61(71.8)$ & $5.587[2.519,12.38]$ & $5.675[2.186-14.73$ & $0.0001^{*}$ \\
\hline Sometimes & $18(10.4)$ & $155(89.6)$ & $1.649[0.7373 .692]$ & 1.139 [0.442-2.932] & \\
\hline Not at all & $10(6.6)$ & $142(93.4)$ & 1 & 1 & \\
\hline
\end{tabular}

town $13.8 \%$ [17]. But the result of this study was much lower than the findings reported in Adwa town 69\% [28], Lumame town 54\%) [27], Zegie Peninsula 69.1\% [29] and in northern Gondar $66.7 \%$ [30]. This could be due to the topographic and study period difference in which the communities would improve their living standard, personal and environmental hygiene through time.

Schistosoma mansoni was the most predominant intestinal helminthes with prevalence of 20 (38.5\%) and $4.9 \%$ from the total participant. This is higher than the study done in Were-Abaye with less than one percent [16]. This might be due to the presence of irrigational areas and flowing river that favor breeding of the intermediate host (snail) in which the infected snails shed cercariae into the water and penetrate the intact human skin. The second intestinal helminth detected was Hookworm with prevalence of $4.14 \%$ from the total participant and 17 (32.7\%) from the detected helminths in stool. This was higher 
than a study done in Chencha town 2.2\% [31] and lower than studies conducted in Babile town 6.7\% [32] and Jimma town $12.9 \%$ [33]. The prevalence of $H$. nana in this study was $1.46 \%$ from the total participant and $6(11.5 \%)$ from the total helminths detected.

Out of the total helminths detected, 49 (94.2\%) were infected with single helminth infection. Lower than study done in Chencha town 19\% [31]. Unlike the studies done in in Adwa town [29] with double infection of $18.4 \%$, in our study area only $3(6 \%)$ of the school children were infected with two different helminths (A. lumbricoides and T. trichiura).

The parents of children at high level of education provides better environment for their children. In contrast to this idea, in our study the odds of intestinal helminths in children with illiterate mothers were $72.8 \%$ less likely to be infected than children with literate mothers at $p=0.001$. This may be due to the similarity of the environmental condition between the schools and living environment.

Human contaminative activities such as open field defecation and use of unhygienic water supply for bathing and drinking favor transmission of intestinal helminths. In our study, students who excrete in open field were about three $(\mathrm{p}=0.023)$ times more likely to have intestinal helminths in their stool than those who defecate in latrine. This was different from the study done in Lumame town [27]. This difference might be due to the difference in topological and environmental sanitation between the two study areas. Students who didn't wash their hands before meal were about nine $(p=0.000)$ times more prone to develop intestinal helminths than those who wash their hands before meal. The helminths might be confined into the nail of the child and may cause infections as they ingest food.

The odds of having intestinal helminths among children who eat unwashed or undercooked vegetables in the stool of the children were about six times higher $(\mathrm{p}=0.000)$ than those who eat washed or cooked vegetables. This was similar with the study done in Lumame town [27]. This might be due to the unwashed or undercooked vegetables and fruits may create a favorable media to eggs of these helminths to infect children.

\section{Conclusion}

The overall prevalence of intestinal helminths recorded in this study was $12.7 \%$. Therefore, Health education programs such as proper personal hygiene should be strengthened in the school and community.

\section{Limitations}

The study did not identify the actual cause of hepatosplenomegaly in S. mansoni positive children. The absence of broader health status of the community was another limitation in which environmental assessment was not conducted around the schools and communities. The study also shares the limitation of the cross-sectional study design.

\section{Abbreviations \\ AOR: adjusted odd ratio; COR: crudes odd ratio; SPSS: Statistics Package for Social Science; STH: soil transmitted helminths; BSc: Bachelor of Science.}

\section{Authors' contributions \\ TST: conceive of data and designed the study, supervised the data collection, performed the analysis, interpretation of data, drafted the manuscript and final approval of the revision for publication. SB: assisted in designing the study, data interpretation and critically reviewed the manuscript. DT: assisted in data interpretation and reviewed the manuscript critically. AA: assisted in analysis, interpretation and reviewed the manuscript critically. GT: assisted in revising the data for intellectual contents, methodology and interpretation of the data with the statistics. Agreement to be accountable for all aspects of the work in ensuring that questions related to the accuracy or integrity of the work are appropriately investigated and resolved. All authors read and approved the final manuscript.}

\section{Author details \\ 1 Department of Laboratory, Aksum University, Po Box: 298, Aksum, Tigray, Ethiopia. ${ }^{2}$ Department of Pediatrics and Child Health Nursing, School of Nurs- ing, Aksum University, Aksum, Tigray, Ethiopia. ${ }^{3}$ Department of Parasitology and Entomology, Mekelle University, Mekelle, Tigray, Ethiopia.}

\section{Acknowledgements}

Authors thanks to Mekelle University and the data collectors, supervisors and study subjects.

\section{Competing interests \\ The authors declare that they have no competing interests.}

Availability of data and materials

All data is available via this manuscript.

\section{Consent for publication}

Not applicable.

\section{Ethics approval and consent to participate}

The study was approved by the institutional research review board of Mekelle University College of health science. An official permission was also secured to Tigray regional health bureau. Then a permission and support letter was written to the education and health office Medebay Zana. Oral consent from school directors and parents and assent from the children was obtained after explaining the purpose of the study. Information was recorded anonymously and confidentiality were assured throughout the study period.

\section{Funding}

No funding was received.

\section{Publisher's Note}

Springer Nature remains neutral with regard to jurisdictional claims in published maps and institutional affiliations. 
Received: 22 April 2018 Accepted: 29 June 2018

Published online: 04 July 2018

\section{References}

1. Organization WH. Soil-transmitted helminthiases: estimates of the number of children needing preventive chemotherapy and number treated, 2009: background = Géohelminthiases: estimations du nombre d'enfants nécessitant une chimioprévention et du nombre de ceux ayant été traités, 2009: Généralités. Wkly Epidemiol Rec. 2011;86(25):257-66.

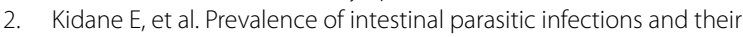
associations with anthropometric measurements of school children in selected primary schools, Wukro Town, Eastern Tigray, Ethiopia. Int J Curr Microbiol Appl Sci. 2014;3(3):11-29.

3. Hotez PJ, et al. Helminth infections: the great neglected tropical diseases. J Clin Invest. 2008;118(4):1311-21.

4. Brooker S, Hotez PJ, Bundy DA. Hookworm-related anaemia among pregnant women: a systematic review. PLoS Negl Trop Dis. 2008;2(9):e291.

5. Nyantekyi LA, et al. Intestinal parasitic infections among under-five children and maternal awareness about the infections in Shesha Kekele, Wondo Genet, Southern Ethiopia. Ethiop J Health Dev. 2010. https://doi. org/10.4314/ejhd.v24i3.68383.

6. Kuete $T$, et al. Prevalence and risk factors of intestinal helminth and protozoa infections in an urban setting of Cameroon: the case of Douala. Am J Epidemiol Infect Dis. 2015;3(2):36-44.

7. Lone R, Syed K, Lone A. Recent patterns and risk factors of intestinal helminthes infection among school children in Kashmir, India. Arch Clin Microbiol. 2011;2(3):2

8. Uneke C. Soil transmitted helminth infections and schistosomiasis in school age children in sub-Saharan Africa: efficacy of chemotherapeutic intervention since World Health Assembly Resolution 2001. Tanzan J Health Res. 2010;12(1):86-99.

9. Braunwald E, et al. Harrison's principles of internal medicine, vol. 15. New York: McGraw-Hill; 2001. p. 1316-23.

10. Teklemariam A, Dejenie T, Tomass Z. Infection prevalence of intestinal helminths and associated risk factors among schoolchildren in selected kebeles of Enderta district, Tigray, Northern Ethiopia. J Parasitol Vector Biol. 2014;6(11):166-73.

11. Papier $\mathrm{K}$, et al. Childhood malnutrition and parasitic helminth interactions. Clin Infect Dis. 2014;59(2):234-43.

12. Nwaneri D, Omuemu V. Intestinal helminthiasis and nutritional status of children living in orphanages in Benin City, Nigeria. Niger J Clin Pract. 2013;16(2):243-8.

13. Adefioye $\mathrm{OA}$, et al. Intestinal helminthiasis among school children in Ilie, Osun State, Southwest, Nigeria. Sierra Leone J Biomed Res. 2011;3(1):43-8.

14. Amenu D. Health impact of intestinal helminth infections among podoconiosis patients. Trends Bacteriol. 2014;1(1):2.

15. Harhay $\mathrm{MO}$, Horton J, Olliaro PL. Epidemiology and control of human gastrointestinal parasites in children. Expert Rev Anti Infect Ther. 2010;8(2):219-34.

16. Seid M, Dejenie T, Tomass Z. Prevalence of intestinal helminths and associated risk factors in rural schoolchildren in Were-Abaye sub-district, Tigray region, northern Ethiopia. Acta Parasitol Glob. 2015;6(1):29-35.
17. Tefera E, Mohammed J, Mitiku H. Intestinal helminthic infections among elementary students of Babile town, eastern Ethiopia. Pan Afr Med J. 2015. https://doi.org/10.11604/pamj.2015.20.50.5251.

18. Tadesse Z, Hailemariam A, Kolaczinski JH. Potential for integrated control of neglected tropical diseases in Ethiopia. Trans R Soc Trop Med Hyg. 2008;102(3):213-4.

19. Hotez $\mathrm{P}$, et al. Recent progress in integrated neglected tropical disease control. Trends Parasitol. 2007;23(11):511-4.

20. Tadesse D, Beyene P. Irrigation practices and intestinal helminth infections in southern and central zones of Tigray. Ethiop J Health Dev. 2009;23(1):48-56.

21. Alemu A, et al. Soil transmitted helminths and schistosoma mansoni infections among school children in Zarima town, northwest Ethiopia. BMC Infect Dis. 2011:11(1):189.

22. Yami A, Mamo Y, Kebede S. Prevalence and predictors of intestinal helminthiasis among school children in Jimma zone; a cross-sectional study. Ethiop J Health Sci. 2011;21(3):167-74

23. Ayalew A, Debebe T, Worku A. Prevalence and risk factors of intestinal parasites among Delgi school children, North Gondar, Ethiopia. J Parasitol Vector Biol. 2011;3(5):75-81.

24. Dejenie T, Asmelash T, Teferi M. Intestinal helminthes infections and re-infections with special emphasis on schistosomiasis mansoni in Waja, North Ethiopia. Momona Ethiop J Sci. 2009. https://doi.org/10.4314/mejs. v1i2.46045.

25. Ayenew A, Meresa K, Abdulkadir M. Baseline survey of Medebay Zana Woreda of Tigray region; 2011

26. Ethiopian Central Stastics Agency. Ethiopian demographic health survey, Addis Ababa, Ethiopia; 2011

27. Wale M, Wale M, Fekensa T. The prevalence of intestinal helminthic infections and associated risk factors among school children in Lumame town Northwest, Ethiopia. J Parasitol Vector Biol. 2014;6(10):156-65.

28. Legesse L, Erko B, Hailu A. Current status of intestinal schistosomiasis and soil transmitted helminthiasis among primary school children in Adwa Town, Northern Ethiopia. Ethiop J Health Dev. 2010. https://doi. org/10.4314/ejhd.v24i3.68384.

29. Abdi M, Nibret E, Munshea A. Prevalence of intestinal helminthic infections and malnutrition among schoolchildren of the Zegie Peninsula, northwestern Ethiopia. J Infect Public Health. 2017:10(1):84-92.

30. Mathewos B, et al. Current status of soil transmitted helminths and Schistosoma mansoni infection among children in two primary schools in North Gondar, Northwest Ethiopia: a cross sectional study. BMC Res Notes. 2014:7(1):88.

31. Abossie A, Seid M. Assessment of the prevalence of intestinal parasitosis and associated risk factors among primary school children in Chencha town, Southern Ethiopia. BMC Public Health. 2014;14(1):166.

32. Tadesse $\mathrm{G}$. The prevalence of intestinal helminthic infections and associated risk factors among school children in Babile town, eastern Ethiopia. Ethiop J Health Dev. 2005;19(2):140-7.

33. Debalke S, Worku A, Jahur N, Mekonnen Z. Soil transmitted helminths and associated factors among schoolchildren in government and private primary school in Jimma town, Southwest Ethiopia. Ethiop J Health Sci. 2013;23(3):237-44.

Ready to submit your research? Choose BMC and benefit from

- fast, convenient online submission

- thorough peer review by experienced researchers in your field

- rapid publication on acceptance

- support for research data, including large and complex data types

- gold Open Access which fosters wider collaboration and increased citations

- maximum visibility for your research: over 100M website views per year

At BMC, research is always in progress.

Learn more biomedcentral.com/submissions 